\title{
An Upshot of Banking Service Quality and Cocoa farmers Satisfaction on Loyalty : The Case of Agricultural Development Bank (ADB), Sefwi-Wiawso
}

\author{
Bentil Anthony Ewusi ${ }^{*}$, He YouShi ${ }^{1}$, Ruth Appiah ${ }^{1}$, Ninnette Attisogbe ${ }^{1}$, Geoffrey Bentum-Micah ${ }^{1}$,
} Emmanuel Bosompem Boadi²

1School of Management, Jiangsu University, Zhenjiang 212013, P.R. China

${ }^{2}$ School of Public Administration, Hohai University, Nanjing 202001, P.R. China

Corresponding Author: Bentil Anthony Ewusi ${ }^{*}$

\section{Article Info \\ Volume 8, Issue 5 \\ Page Number : 67-77 \\ Publication Issue \\ September-October-2021}

\section{Article History}

Accepted : 02 Sep 2021

Published : 08 Sep 2021

\section{ABSTRACT}

This study makes an empirical study on the relationship between service quality, customer satisfaction and customer loyalty in the banking sector for cocoa farmers of Sefwi-Wiawso in the western-north region of Ghana. Based on the servqual model the researcher constructed a model which brings to light the relationship amid quality of service and customer loyalty in the banking service sector using $\mathrm{ADB}$ as a case. The paper puts forward the relevant research hypothesis and develops standard measurements based on the data obtained in the survey questionnaire. The convenient sampling method was applied with 300 customers as samples from the Bank. In all, 360 questionnaires were successfully completed and analyzed. Descriptive statistics, correlation analysis, and regression analysis were carried out using Statistical Package for Social Sciences software (SPSS) to estimate the relationship between variables. The overall results of this study show that there is a positive and significant relationship between all constructs. Service quality and Customer satisfaction positively affect customer loyalty. The study recommends that strategic services bordering on the servqual dimensions should be introduced to provide high-quality services. This will also improve customer loyalty in the long run.

Keywords : Service quality, customer satisfaction, customer loyalty, ADB, Sefwi-Wiawso, Cocoa Farmers

\section{INTRODUCTION}

Customer loyalty is essential in creating and maintaining a competitive advantage in the service industry worldwide. It is believed that there are many economic advantages attributed to retaining loyal customers instead of looking for new ones. In light of this, both industry practitioners and researchers pay much more attention to customer loyalty studies, Ndubisi [1] as cited in [2]. To remain 
competitive, most Commercial Banks build and enhance customer relationships that deliver value beyond their core competitors' value [3]. There are several benefits incurred from this approach. For example, it helps improve companies performance, profitability, business referrals and increased publicity, customer share, and competitive positioning [4] as in [5]

Anabila [6] maintains that a slight increase in loyal customers can substantially increase profitability. Ensuring customer satisfaction and long-term retention are one of the most critical tasks for managing a service company; banks. High level of customer satisfaction is the primary tool for creating long-term Loyalty, business stability, growth, and long-term development [7]. Therefore, customer satisfaction is an important factor to consider when managing a modern company faced with new challenges like the banking sector. Moreover, loyal customers are more profitable because they are attached to the Bank and thus are easier to serve than non-loyal customers are.

Furthermore, the longer a loyal customer stays with a firm, the more profitable it is to that firm [2]. Notwithstanding, based on the quality of service provided by the banks to customers, there is a quick change of mind by customers, thus moving from one Bank to another to assess varied banking services. It should be highlighted that the researcher decided to undertake this study to evaluate the interrelationship between service quality, customer satisfaction, and customer loyalty from cocoa farmers perspectives in the Sefwi-Wiawso branch of the Agricultural Development Bank (ADB) in the Sefwi Municipality of the Western North region of Ghana.

The Agricultural Development Bank of Ghana, commonly known as Agricultural Development Bank or $\mathrm{ADB}$, is a government-owned development and commercial Bank in Ghana. This bank is the first financial institution established by the Government of Ghana as a development bank. It is one of the commercial banks licensed by the Bank of Ghana, the national banking regulator. ADB was established in 1965 by the Act of Parliament in order to solve the numerous banking needs of the Ghanaian agricultural sector profitably. The Bank is an extensive development and commercial Bank. As of April 2010, $\mathrm{ADB}$ was the leading financial institution in agricultural financing in Ghana, responsible for 35\% of the total bank industry financing of agriculture. In September 2010, the Bank was recognized as 'Bank of The Year' at the Africa Investor Agribusiness Awards in Durban, South Africa, and the first institution recognized at this annual event. The Bank engages in other types of banking in addition to providing agricultural loans. The range of services offered includes (a) Development Banking (b) Corporate Banking (c) Personal Banking (d) International Banking (e) Diaspora Banking Services (f) Treasury Management Services and (g) Money Transfer Services, in partnership with Western Union.

Firms that aim to remain competitive in the marketplace need to build and enhance relationships with loyal customers. The outcome is often positive and examples are increase in profitability, existing customers making referrals which improves publicity. This also help in advancing customer share, and competitive positioning [4], as cited in [5]. Given that it is increasingly becoming difficult to achieve customer loyalty in a competitive environment. Researchers have attempted various theories and models like the servqual model to investigate the predictors of customer loyalty in the service industry. In reviewing these models, it has been established that service quality, customer satisfaction, perceived value, trust, and commitment are the most critical variables in creating and maintaining customer loyalty [8-10] as cited in [11]. This study focuses primarily on the relationship between service quality, customer satisfaction, and customer loyalty in ADB with regards to cocoa farmers selected from SefwiWiawso, a cocoa farming community. It examines the impact of quality service on the cocoa farmers satisfaction and the relationship between customer 
satisfaction and their level of Loyalty to the ADB bank and its services.

Service quality, customer satisfaction and Loyalty are key elements that need to be deliberated upon. [12], opined that an organization that systematically satisfies its clients enjoys higher retention levels and larger gain because of increased customer loyalty. For this cause, each company works tirelessly daily to win the consumers by pleasing them so that they become loyal customers to their brands to increase sales and profit. When customers awareness for a particular product is high, they're likely to select the products because consumers form their preferences relative to perceptions and attitudes about the brands competing in their minds [13]. To gain the loyalty of the customers, firms should build relationships with the purchasers. To create a relationship with customers, firms have to conduct analysis to answer queries on how the purchasers create Loyalty and whether they are pleased with what the organization provides to them as provided in terms of product quality, service quality, price, etc.

The increasing range of companies coupled with the keen competition in the market nowadays, every company desire to be the customer's " 1 st" alternative [14]. To achieve this, organizations need to find answers to challenges regarding consumers consumption habits. The company should determine whether consumers' consumption habit has been improved or well served. The company should also assess popularity of their brand and also check the availability of the product to all who may need it [15]. The products should be within arms reach of desire, if companies want to make their product competitive in the market. This requires constant investigation to lead the organizations to their twin objective of satisfying their customers and making profits. Service quality usually predicts a large percentage of client satisfaction [16]. The research interest on service quality alone for this study is because service quality has been proven to be the best determinant of customer satisfaction hence Loyalty. In addition, providing quality services is one of the main targets for management concerning customer satisfaction in today's business environment.

Nevertheless, there are few researches which concentrate on the quality of service farmers experience, especially concerning the most prominent leading financial institution in agricultural financing in Ghana, the Agricultural Development Bank (ADB). The study would not only provide practical information to the stakeholders of banks, marketing professionals, and policymakers of the developmental banking industries in Ghana, it would also add to the existing literature on this subject for further studies. The banking industry stakeholders mentioned here mainly refer to the management, shareholders, and directors of banks in Ghana, particularly those of the public banks. The global trend and challenges in services in today's business world showed that service corporations square measure underneath constant and dynamic amendment. That is to say customers have become so dynamic in recent times which makes it difficult to predict their level of satisfaction. In view of this, constant studies on the the factors which affects customer loyalty and good services can be not be ignored.

This research seeks to resolve the following questions:

(1) What are the levels of customer satisfaction with the services provided by ADB to the cocoa farmers of Sefwi-Wiawso in the western north region of Ghana's western region?

(2) What is the link between service quality and customer satisfaction in ADB's banking services to cocoa farmers?

(3) What is the connection between customer satisfaction and customer loyalty to cocoa farmers?

(4) Does the quality of service affect the Loyalty of the service patrons at the ADB banking facility?

Based on our downside space discussion, our analysis problem is developed as follows: 
I. Are customers satisfied with service quality at the Sefwi-Wiawso branch of the Agricultural Development Bank (ADB)?

II. Are customers loyal because they are satisfied with the Sefwi-Wiawso branch of the Agricultural Development Bank (ADB)?

III. Does the quality of banking service at the SefwiWiawso branch of the Agricultural Development Bank (ADB) affect customer loyalty?

From the model as mentioned earlier, the following hypothesis is developed:

H1: Service quality has a positive and significant relationship with customer satisfaction.

H2: Customer satisfaction has a positive and significant relationship with customer loyalty.

H3: Service quality has a positive and significant relationship with customer loyalty.

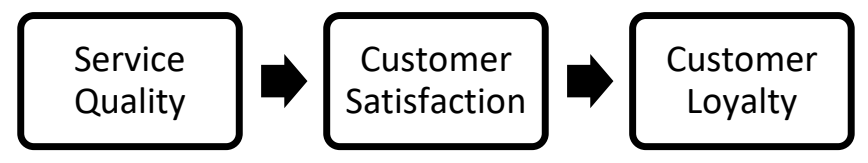

Figure 1: Presents the conceptual structure of the study

Source: The researcher's construct.

\section{METHODOLOGY}

A quantitative survey was used to test the research model. The quantitative analysis approach gathers numerical data and analyses it with statistical statistics [17]. "Quantitative research methods address questions on relationships within observable variables to understand, predict, and monitor a phenomenon," according to [18] Survey questionnaires were pretested using a small number of respondents to ensure high internal consistency of the measures. Consequently, minor changes were made, and the questionnaire was administered to customers who had visited the Agricultural Development Bank (ADB), Sefwi-Wiawso. The research model consisted of seven basic constructs. Respondents indicated the extent of their agreement or disagreement with the measures on a Likert scale from 1 (strongly disagree) to 5 (strongly agree). The scale was adapted mainly from Parasuraman and Berry [19]. A total of 300 Customers of Agricultural Development Bank (ADB), SefwiWiawso, were surveyed based on convenience sampling techniques. Out of the total completed questionnaire, 360 were usable. Data collection spanned the period between October and December of 2020. The analysis of the data was performed using the SPSS package. This involved descriptive analysis. Data were cleaned before analysis to ensure that they were correctly captured from source documents. Regression analysis was used to assess the quality of services on Customer satisfaction and Customer satisfaction on Customer loyalty. T-values were considered significant at a confidence level of $>2$ and $\mathrm{P}$-values at the marginal error of $<0.05$. Correlation and regression analysis were applied to analysis the date while Pearson correlation analysis was conducted to determine the direction, strength, and significance of the bivariate relationships between service quality, customer satisfaction and customer loyalty.

The questionnaire contained two sections, namely "A and B." Section 'A' had questions on demography (age, gender, education and occupation). In contrast, section 'B' included questions on customer satisfaction with service quality and Loyalty of the customer to the Agricultural Development Bank (ADB), SefwiWiawso. These included (rating of service quality (tangibility, responsiveness, empathy, reliability and assurance), customer service (promptness, attitude and competence). This research used closed-ended questions; the author provides answers, and the recipients choose from the alternatives given.

\section{RESULTS}

Only 360 valid responses were used in the analysis. The presentation of the outcome started with respondents ' social profiles. Age, gender, educational level, and employment status were the factors 
included in this section. 52.8\% were female, while $47.2 \%$ were male. Nonetheless, $33.8 \%$ of respondents' ages ranged from 18 to 29 , while $45 \%$ of respondents ages ranged from 30 to 44 . Furthermore, $15.4 \%$ of respondents' ages ranged from 45 to 59 , while $5.8 \%$ were 60 years and above. Also, only $16.7 \%$ of the respondents had Bachelor's degrees or above.

Table 1 : Respondents ' Social Profiles

\begin{tabular}{|c|c|c|c|}
\hline Items & & $\begin{array}{l}\text { Frequency } \\
\mathrm{N}=360\end{array}$ & $\begin{array}{l}\text { Percentage } \\
(\%)\end{array}$ \\
\hline \multirow[t]{2}{*}{ Gender } & Female & 190 & 52.8 \\
\hline & Male & 170 & 47.2 \\
\hline \multirow[t]{4}{*}{ Age } & 18- 29 & 122 & 33.8 \\
\hline & $30-44$ & 162 & 45.0 \\
\hline & $45-59$ & 54 & 15.4 \\
\hline & 60 and above & 22 & 5.8 \\
\hline \multirow{6}{*}{$\begin{array}{l}\text { Education } \\
\text { level }\end{array}$} & Basic & 154 & 42.8 \\
\hline & certificate & & \\
\hline & $\begin{array}{l}\text { College } \\
\text { certificate }\end{array}$ & 131 & 36.4 \\
\hline & Bachelor's & 60 & 16.7 \\
\hline & $\begin{array}{l}\text { degree an } \\
\text { above }\end{array}$ & & \\
\hline & Others & 15 & 4.1 \\
\hline
\end{tabular}

\section{Factor Analysis and Reliability}

Results of $\mathrm{KMO}$ and Bartlett's test reveal that variables are highly significant. Cronbach's alpha was used to measure the internal consistency of each identified construct. The reliability of each construct was acceptable, while Cronbach's alpha per the statistical rule of thumb was above 0.7. Thus, all measures used in the main study achieved adequate levels of reliability. Generally, all scales achieved satisfactory levels of reliability as recommended by [20]. From the data analysis, the Cronbach's Alpha was 0.855 for the nine (9) items, and so the subsequent analyses were conducted with the data.
Table 2 : Validity Statistics of the Data.

KMO AND BARTLETT'S TEST

KAISER-MEYER-OLKIN MEASURE OF

0.819

SAMPLING ADEQUACY.

BARTLETT'S TEST APPROX.

1091.655

OF SPHERICITY CHI-SQUARE

DF

36

SIG.

.000

Source: Author's contribution using SPSS

\section{Pearson's Correlation}

Table 3 : Pairwise Correlation of service quality, customer satisfaction, and Loyalty

\begin{tabular}{llll}
\hline VARIABLES & $\begin{array}{l}\text { SERVICE } \\
\text { QUALIT } \\
\text { Y }\end{array}$ & $\begin{array}{l}\text { CUSTOMER } \\
\text { SATISFACTI } \\
\text { ON }\end{array}$ & $\begin{array}{l}\text { LOYALT } \\
\text { Y }\end{array}$ \\
\hline SERVICE & 1.000 & & \\
QUALITY & & & \\
CUSTOMER & $.452^{* *}$ & 1.000 & \\
SATISFACTI & & & \\
NN & & & \\
CUSTOMER & $.666^{* *}$ & $.597^{* *}$ & 1.000 \\
LOYALTY & & &
\end{tabular}

${ }^{* *}$ Correlation is significant at the 0.01 level (2-tailed).

This study shows the lowest correlation between service quality and customer satisfaction (0.452), followed by the Correlation between customer loyalty and customer satisfaction (0.597). This implies that customer satisfaction increases with the level of improvement of the quality of the services. In addition, Customer satisfaction is a determinant factor of the Loyalty of the Customers to the organization. This supports previous literature that Customer satisfaction is a mediating element of quality services to Customer loyalty. The Correlation between loyalty and quality services (0.666) is the highest among all (Table 3). Though pairwise correlations provide preliminary evidence that the relationship between variables is weak, the multivariate linear regression analysis was used to determine the effect of service 
quality on rate of customer satisfaction as (service quality $\rightarrow$ Customer satisfaction) while Customer satisfaction also relates directly to customer loyalty (Customer satisfaction $\rightarrow$ Customer loyalty).

\section{REGRESSION ANALYSIS}

\section{Service Quality and Customer satisfaction}

To determine the effect of service quality on customer satisfaction, a regression analysis was assessed. The results are presented in Table 4 .

Table 4 : Effect of Service Quality on Customer satisfaction

\begin{tabular}{|c|c|c|c|c|c|c|}
\hline \multirow{7}{*}{\multicolumn{2}{|c|}{ MODEL }} & \multirow{3}{*}{\multicolumn{2}{|c|}{$\begin{array}{l}\text { UNSTANDA } \\
\text { RDIZED } \\
\text { COEFFICIEN }\end{array}$}} & STANDA & $\mathrm{T}$ & \multirow[t]{7}{*}{ SIG } \\
\hline & & & & RDIZED & VA & \\
\hline & & & & COEFFICI & LUE & \\
\hline & & \multicolumn{2}{|l|}{ TS } & ENTS & & \\
\hline & & B & STD. & BETA & & \\
\hline & & & ERRO & & & \\
\hline & & & $\mathrm{R}$ & & & \\
\hline 1 & (CONST & & .182 & & 10.6 & . \\
\hline & ANT) & 1.9 & & & 34 & 000 \\
\hline & & 37 & & & & \\
\hline & SERVIC & .42 & .055 & .452 & 7.82 & . \\
\hline & $\mathrm{E}$ & 7 & & & 2 & 000 \\
\hline & QUALI & & & & & \\
\hline & $\mathrm{TY}$ & & & & & \\
\hline
\end{tabular}

\section{A. DEPENDENT VARIABLE: CUSTOMER SATISFACTION}

Table 4 presented the assessed regression results of the service quality on customer satisfaction. The findings show that the coefficient of service quality was significant at $.000 \mathrm{p}$-value and t-value of .427 levels, suggesting that service quality has a significant positive effect on customer satisfaction. Thus, the study confirms with the literature that improvements in service quality may be beneficial to the Agricultural Development Bank (ADB), Sefwi-
Wiawso, as it helped promote customer satisfaction. In the univariate linear regression analysis, it was noted that a unit increase in the scores of service quality increases the levels of customer satisfaction by $43 \%$ (Table 3 ), and the effect of the service quality on the model is significant at $(\mathrm{p}<0.001)$. The overall model is presented by the equation below:

Customer satisfaction $i=1.937_{i}+0.427$ (service quality)

\section{Customer satisfaction and Customer loyalty}

To determine the effect of customer satisfaction on customer loyalty, a regression analysis was assessed. The results are presented in Table 5.

Table 5: Regression analysis of Customer satisfaction on Loyalty

\begin{tabular}{lllll}
\hline MODEL & UNSTANDAR & STANDAR & T & SIG \\
& DIZED & DIZED & VAL & $\cdot$ \\
& COEFFICIEN & COEFFICI & UE & \\
& TS & ENTS & & \\
\cline { 2 - 3 } & B & STD. & BETA & \\
& & & \\
& & &
\end{tabular}

$\begin{array}{llllll}1 \text { (CONSTA } & .96 & .199 & & 4.82 & .00 \\ \text { NT) } & 1 & & & 3 & 0 \\ \text { CUSTOM } & .66 & .058 & .597 & 11.4 & .00 \\ \text { ER } & 8 & & & 81 & 0 \\ \text { SATISFA } & & & & & \\ \text { CTION } & & & & & \end{array}$

\section{B. DEPENDENT VARIABLE: CUSTOMER LOYALTY}

The results from Table 4 are based on the investigation of the effect of customer satisfaction on customer loyalty; the findings showed that a unit increase in the scores of the level of customer satisfaction to the Bank's services increased the scores of customer loyalty by $67 \%$. Moreover, considering the results of the regression analysis, customer satisfaction exerts a positive (0.668) and statistically significant $(\mathrm{t}=11.481 ; \mathrm{p}<0.000)$ effect on customer loyalty. In the hypothesis testing of the relationship between customer loyalty and customer satisfaction, 
it was founded that customer satisfaction was significantly influencing the level of Customer loyalty at $(\mathrm{p}<0.001)$ confidence level. The model was presented by the equation below:

$$
\text { Loyalty } i=0.961_{i}+0.668 \text { (customer satisfaction) }
$$

\section{Service Quality and Customer loyalty}

To determine the effect of Service quality on customer loyalty, a regression analysis was assessed. The results are presented in Table 6 .

Table 6 : Regression analysis of Service quality on Loyalty

\begin{tabular}{lllll}
\hline MODEL & UNSTANDAR & STANDAR & T & SIG \\
& DIZED & DIZED & VAL & . \\
& COEFFICIENT & COEFFICIE & UE & \\
& S & NTS & \\
\cline { 2 - 3 } & B & STD. & BETA & \\
& & &
\end{tabular}

1 (CONST $\quad .86 \quad .187$ ANT) 1

$\begin{array}{lll}\text { SERVIC } & .76 & .055 \\ \text { E } & 8 & \\ \text { QUALI } & & \end{array}$
.687 TY

\section{DEPENDENT VARIABLE: CUSTOMER LOYALTY}

The results from Table 6 are based on the investigation of the effect of the Service quality on customer loyalty; the findings showed that a unit increase in the scores of the level of Service quality to the Bank's services increased the scores of customer loyalty by $77 \%$. The hypothesis test on the relationship between Service quality and customer satisfaction uncovered that Service quality had a significant influence on the level of Customer's loyalty at $(\mathrm{p}<0.001)$, confidence level. The model was presented by the equation below:
Loyalty $i_{i}=0.861_{i}+0.768$ (Service Quality) $i$ (3)

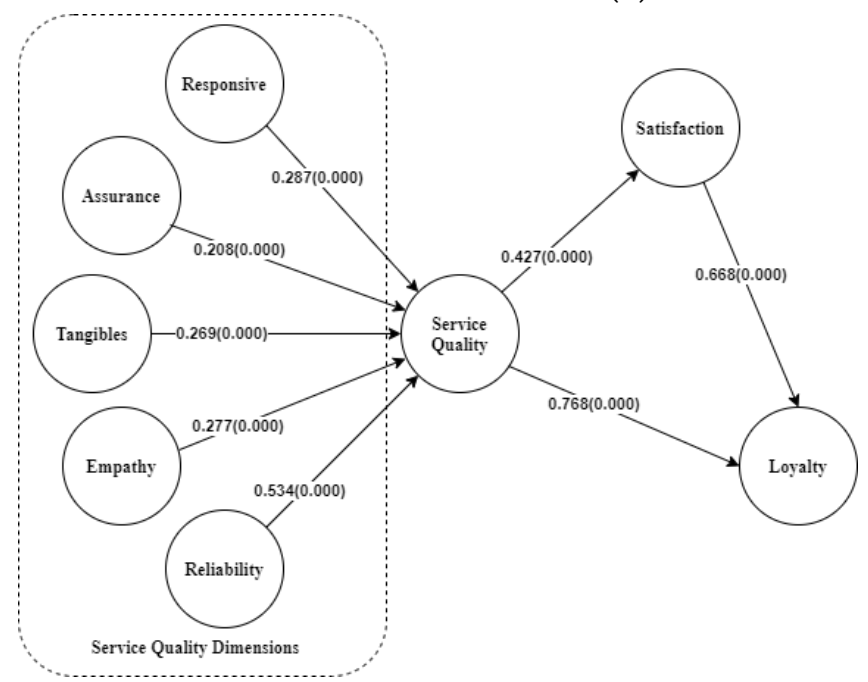

Figure 2: A combined conceptual path model of regression analysis.

\section{DISCUSSION}

The assessment of the impact of service quality on customer satisfaction is overwhelming considering its predictive relevance that the regression analysis .00 results would indicate service quality exerts a positively strong $(\beta=0.427 ; t=7.822 ; \mathrm{p}<0.001)$ effect 00 on customer satisfaction. The test results support the 0 hypothesis (H1) that service quality significantly influences customer satisfaction; this can be interpreted as a unit rise in service quality scores that raises customer satisfaction rates by $42.7 \%$ (Table 4 ). This reveals that the customer's perception of the quality of service delivered is the most influential variable on customer's loyalty. Therefore, Agricultural Development Bank (ADB), SefwiWiawso, has to place a keen interest in providing excellent services to customers that they may be satisfied with the Bank's services. As the quality of service has become an increasingly keen commodity in the marketplace, studying the customer experience could help professionals better understand the customer's perspectives on service delivery and improve customer satisfaction. 
Ultimately, this observation is confirmed by enormous previous research findings in different countries in this service sector. The most dominant results reveal that service quality perception is the greatest determinant of customers satisfaction $[3,15$, 16, 21-25]. Though this study is limited to the banking industry, the results are also the same in other service sectors like the airline industry, the education sector, the healthcare industry, the hospitality industry, and several others. The test results support the hypothesis (H2) that customer satisfaction influences customer loyalty intention. Also, this study's overall results show a positive and significant relationship between all constructs. Service quality is positively related to Customer satisfaction $(\beta=0.427 ; \mathrm{t}=7.822 ; \mathrm{p}<0.001)$, and Customer satisfaction is positively related to customer loyalty $(\beta=0.668 ; \mathrm{t}=11.481 ; \mathrm{p}<0.001)$ and same amid the relation; service quality and customer loyalty $(\beta=0.768 ; \mathrm{t}=13.964 ; \mathrm{p}<0.001)$. This means that satisfying the customers tends to make the customers more loyal to the Bank and its services. From the results, enhancing customer satisfaction scores by a unit raises the loyalty intention rates by $66.8 \%$. Min, Kim [26] indicated that higher customer satisfaction leads to a higher retention intention in the same vein. William, Appiah [27] confirmed that better satisfaction builds better Loyalty among Customers. Given these, banks are regularly assessing the factors that make customers satisfied with service provision.

\section{CONCLUSION AND IMPLICATIONS}

This study investigates the role of service quality and its effect on customer satisfaction and customer loyalty to determine their underlying relationships and implications on banking services; using evidence from Agricultural Development Bank (ADB), SefwiWiawso. Customers' satisfaction and Loyalty were identified as correlates of successful marketing performance in line with extant literature.
Firstly, the results showed a positive and significant relationship between service quality and customer satisfaction in line with previous studies $[5,15,23$, 28]. Secondly, the study found that customer satisfaction significantly influenced customer loyalty. Lastly, the study shows that, service quality has a positive and significant impact on customer loyalty.

The significance of the relationships between service quality dimensions was also considered to highlight the nature and degree of these emphasis. This is often required by banking practitioners in their service quality practices to achieve service differentiation and increase competitive leverage. Furthermore, policymakers of banking service providers seeking to increase customer satisfaction and customer loyalty should focus on improving customers' perceived drivers identified in 'SERVQUAL' scale (reliability, responsiveness, assurance, empathy, tangibles) to increase their chances of success in line with $[15,23$, 28]. This implies customers build confidence in the bank if banking services delivered are customerfriendly and interactive especially at service encounters. Customers also believe in banks which provides quick response to their requests, with a high degree of competence and genuine commitment. Finally, if the physical environment is visually appealing and banking equipment is up-to-date, the cumulative effect will be positive reciprocal outcomes of customer satisfaction and customer loyalty [29, 30]. Customer satisfaction and customer loyalty have long been touted as crucial drivers of firm profitability and long-run competitive advantage [31, 32].

Additionally, the banks stand to gain when they ensure service excellence by way of customer satisfaction and customer loyalty, since customers are the prime determinants of quality and satisfaction. This can be achieved by mainstreaming customers' satisfaction surveys using the modified servqual scale to gauge customers' perspectives periodically. The customers participation marks a significant landmark 
towards a holistic banking paradigm away from the traditional profit-oriented approach.

Furthermore, such a feedback system can help shape policy initiatives to improve banking decisions and outcomes. This aligns with Corrigan, Donaldson [33] cited in [34], who posited that a good indicator of banking service quality is that it must be customeroriented. Finally, the study is a significant contribution to knowledge in the banking sector in Ghana, since there is a knowledge gap in empirical research linking service quality to customer satisfaction and customer loyalty as hallmarks of sustainable competitive advantage in the rural banking sector since researchers have primarily focused on other predominant sectors in the economy. However, the study has several limitations worth noting. First the study used convenience sampling, which limits the representativeness of findings. Future studies may consider a form of random sampling. Second, only customers were covered and not the service providers. Future studies may consider broadening the scope to provide a more comprehensive outlook to both clients and service providers.

\section{Conflicts of Interest}

The authors declare that they have no competing interests.

\section{REFERENCES}

[1]. Ndubisi, N.O., Relationship marketing and customer loyalty. Marketing intelligence \& planning, 2007.

[2]. Khadka, K. and S. Maharjan, Customer satisfaction and customer loyalty. Centria University of Applied Sciences Pietarsaari, 2017. 1(10): p. 58-64.

[3]. Ngo, V.M. and H.H. Nguyen, The relationship between service quality, customer satisfaction and customer loyalty: An investigation in
Vietnamese retail banking sector. Journal of Competitiveness, 2016.

[4]. Hennig-Thurau, T., Customer orientation of service employees: Its impact on customer satisfaction, commitment, and retention. International journal of service industry management, 2004.

[5]. Gorondutse, A.H., H. Hilman, and M. Nasidi, Relationship between corporate reputation and customer loyalty on Nigerian food and beverages industry: PLS approach. International Journal of Management and Business Research, 2014. 4(2): p. 125-136.

[6]. Anabila, P., Service quality: A subliminal pathway to service differentiation and competitive advantage in private healthcare marketing in Ghana. Health marketing quarterly, 2019. 36(2): p. 136-151.

[7]. Mohammad, A.A.S. and S.Y.M. Alhamadani, Service quality perspectives and customer satisfaction in commercial banks working in Jordan. Middle Eastern Finance and Economics, 2011. 14(1): p. 60-72.

[8]. Kim and S.B. Choi, Social Commerce Service Quality and Word-of-Mouth Intention: An Application of the ExpectationDisconfirmation Theory, 2019. 41(4): p. 47-73.

[9]. Liang, L.J., H.C. Choi, and M. Joppe, Exploring the relationship between satisfaction, trust and switching intention, repurchase intention in the context of Airbnb. International Journal of Hospitality Management, 2018. 69: p. 41-48.

[10]. OPaul, J., A. Mittal, and G. Srivastav, Impact of service quality on customer satisfaction in private and public sector banks. International Journal of Bank Marketing, 2016.

[11]. Priporas, C.V., et al., Service quality, satisfaction, and customer loyalty in Airbnb accommodation in Thailand. International Journal of Tourism Research, 2017. 19(6): p. 693-704. 
[12]. Wicks, A.M. and C.J. Roethlein, A satisfactionbased definition of quality. The Journal of Business and Economic Studies, 2009. 15(1): p. 82.

[13]. Gohain, K., S. Thambiah, and T.C. Hong, A Comprehensive Model with Six Service Quality Dimensions, Satisfaction and Loyalty: An Empirical Investigation into the Public Hospitals in Malaysia. International Journal of Economics \& Management Sciences, 2018. $7(01)$.

[14]. Nyadzayo, M.W. and S. Khajehzadeh, The antecedents of customer loyalty: A moderated mediation model of customer relationship management quality and brand image. Journal of Retailing and Consumer Services, 2016. 30: p. 262-270.

[15]. Bentum-Micah, G., et al., Spotting the Critical Service Quality Determinants in the Ghanaian Retail Banking: Importance and Effects. European Journal of Business Management, 2019.

[16]. Ali, M. and S.A. Raza, Service quality perception and customer satisfaction in Islamic banks of Pakistan: the modified SERVQUAL model. Total Quality Management \& Business Excellence, 2017. 28(5-6): p. 559-577.

[17]. Almalki, S.J.J.o.e. and learning, Integrating Quantitative and Qualitative Data in Mixed Methods Research--Challenges and Benefits. 2016. 5(3): p. 288-296.

[18]. Eyisi, D.J.J.o.E. and Practice, The usefulness of qualitative and quantitative approaches and methods in researching problem-solving ability in science education curriculum. 2016. 7(15): p. 91-100.

[19]. Parasuraman, A. and L.L. Berry, Delivering quality service: Balancing customer perceptions and expectations. 1990: Free Press.

[20]. Chiad, J.S., et al., Buckling investigation of isotropic composite plate reinforced by different types of powders. 2018. 9(09): p. 305317.

[21]. Bedi, M., An Integrated Framework for Service Quality, Customer Satisfaction and Behavioral Responses in Indian Banking Industry--A Comparison of Public and Private Sector Banks. Journal of Services Research, 2010. 10(1).

[22]. Belás, J. and L. Gabčová, The relationship among customer satisfaction, loyalty and financial performance of commercial banks. Economics Management decision, 2016.

[23]. Boateng, E., M. Amponsah, and A. Serwaaadomako, Impact assessment of ATM on customer satisfaction of banks in Ghana:a case study of Kumasi,Ghana. Mpra Paper, 2014.

[24]. Kadri, A.-B.Y., A. Bunyaminu, and S. Bashiru, Assessing rural banks effectiveness in Ghana. International Business Research, 2013. 6(3): p. 140.

[25]. Kyei, D.A. and B. Narteh, Relationship Marketing Practices and Customer Satisfaction in the Ghanaian Banking Sector. International Journal of Bank Marketing, 2016. 12(12): p. 1523.

[26]. Min, H., et al., Efficient, stable solar cells by using inherent bandgap of $\alpha$-phase formamidinium lead iodide. 2019. 366(6466): $\mathrm{p}$. 749-753.

[27]. William, O., E.E. Appiah, and E.A. Botchway, Assessment of customer expectation and perception of service quality delivery in Ghana commercial bank. Journal of Humanity, 2016. 4(1): p. 81-91.

[28]. Moghavvemi, S., S.T. Lee, and S.P. Lee, Perceived overall service quality and customer satisfaction. International Journal of Bank Marketing, 2018.

[29]. Jamaluddin, J. and E. Ruswanti, Impact of service quality and customer satisfaction on customer loyalty: a case study in a private hospital in Indonesia. Journal of Business Management Decision, 2017. 19(5): p. 23-33. 
[30]. Lindgreen, A., et al., Value in business and industrial marketing: Past, present, and future. Industrial Marketing Management, 2012. 41(1): p. 207-214.

[31]. Baabdullah, A.M., et al., Consumer use of mobile banking (M-Banking) in Saudi Arabia: Towards an integrated model. International Journal of Information Management, 2019. 44: p. 38-52.

[32]. Ozili, P.K., Banking stability determinants in Africa. International Journal of Managerial Finance, 2018.

[33]. Corrigan, J., et al., A new health system for the 21st century. 2001.

[34]. Osei-Frimpong, K., Patient participatory behaviours in healthcare service delivery: Selfdetermination theory (SDT) perspective. Journal of Service Theory Practice, 2017. 27(2): p. $453-474$.

\section{Cite this article as :}

Bentil Anthony Ewusi, He YouShi, Ruth Appiah, Ninnette Attisogbe, Geoffrey Bentum-Micah, Emmanuel Bosompem Boadi, "An Upshot of Banking Service Quality and Cocoa farmers Satisfaction on Loyalty : The Case of Agricultural Development Bank (ADB), Sefwi-Wiawso", International Journal of Scientific Research in Science and Technology (IJSRST), Online ISSN : 2395-602X, Print ISSN : 23956011, Volume 8 Issue 4, pp. 67-77, SeptemberOctober 2021. Available at doi : https://doi.org/10.32628/IJSRST21851 Journal URL : https://ijsrst.com/IJSRST21851 